\title{
Impact of various types of anti-hail nets on light exposure in orchards and quality parameters of apples- a rewiev
}

\author{
Marinka BRGLEZ SEVER, Stanislav TOJNKO, Tatjana UNUK ${ }^{\star}$ \\ University of Maribor, Faculty of Agriculture and Life Sciences, Pivola 11, Hoče
}

\begin{abstract}
The new Common Agricultural Policy (CAP) has been designed to shrink funds that Hungarian agricultural reform will ineNowadays, anti-hail nets are a part of basic equipment in a modern apple orchards. They decrease the risks of apple production and thus allow regular and quality apple harvest. Colours of nets differently obstruct the passing of light through the net, which directly affects some quality parameters of the yield, especially the fruit skin colour. The article includes a brief overview of studies associated with the impact of light exposure under different types of anti-hail nets on quality of apple fruits, as well as investigations which deal with adaptation of various technological measures, such as the use of reflective ground foil. A part of data from the existing literature explains the effect of anti-hail net usage on forming a microclimate under the net, and consequently, its effect on the development and dynamics of diseases and pests.
\end{abstract}

Key words: Anti-hail net, light, microclimate, apples, yield quality

\section{INTRODUCTION}

The benefits of anti-hail net usage are reducing the alternate bearing incidence due to protection of fruit trees, reduction of sunburn in hot years, protection against birds and insects, lesser impact of strong wind and continuous market supply of high quality fruits. Anti-hail nets point to the importance of consistently carrying out the technical support measures with the intention of balancing the growing conditions, mostly the light exposure of the fruit in the tree crown. (Germšek 2010, Germšek and Unuk 2014). As the distinct advantages of antihail net usage, Klein (2000) states a smaller day and night temperature variations under the net, a stronger and more uniform growth, and a partial protection against frost and of heavy rain.

Another benefit of using the anti-hail nets, as seen in practice, is also the possibility of combining it with the plant support systems. Due to the elimination of production risks, which in some regions poses a distinct problem because of the hail, the placement of anti-hail nets allows for a quicker return of the invested assets in aorchard establishment, earlier and more regular yields of high quality, and thus a higher economy of apple production (Germšek in Unuk 2014).

\section{Anti-hail net light transmittance}

Light has a crucial role when it comes to the intensity of the photosynthesis, differentiation of floral buds, and consequently also affects the quality of fruit. It is also a key factor affecting colour, taste and resilience of fruits (Jazbec and Hanzak 1982, Holzwarth 2008).

Photosynthetically active radiation (PAR), which is needed for photosynthesis, has the wavelength between 400 and $700 \mathrm{~nm}$. Approximately from 85 to $95 \%$ PAR - radiation is absorbed by a leaf, the rest is either reflected or penetrates the leaf (Štampar et al. 2002). The level of light is decreased for approximately $7 \%$ (PAR) - 20\% (UV) with a white net (which allows for the maximum light exposure under a net): $11 \%$ (PAR) $-28 \%$ (UV)with a red-white net, 12\% (PAR) $23 \%$ (UV) with a green-white net, $13 \%$ (PAR) with a light grey net, $15 \%$ (PAR) - 26\% (UV) with a black and green, $16 \%$ 
(PAR) - 23\% (UV) with a black net and 18\% (PAR) - 29\% (UV) with a red net, measured 50 centimetres below the net. The level of UV light is decreased by $29 \%$ with a black net (Blanke 2007). With a grey net the level is decreased by $13 \%$ (PAR), whereas with a black net by $18 \%$ (PAR) (Blanke 2007, cited.).

Larcher (2003) states that the leaves exposed to the sunlight, compared to those in the shade, have a higher level of net photosynthesis. The leaves on the trees protected by anti-hail net could behave similarly to the leaves in the shade, due to somehow decreased exposure to light. Widmer (2001) claims that swings in day temperature show thet weather (cloudiness, fog) can affect the light exposure to a much higher degree than the anti-hail net; he states that the assimilation of leaves experiences a small decrease only on cloudy days, while it remains unchanged on sunny days.

A part of UV rays is transmitted through the nets as a visible light, therefore they do not represent additional protection against UV rays with the wavelength above $300 \mathrm{~nm}$. Trees and fruits under such nets are, during their growth, exposed to the same level of UV - A and partially UV - B radiation as well as the level of visible light. The effect of UV radiation on plants depends on strength of the visible light and is even stronger when the light is weaker, for example in dapple shade, in cloudy weather and under the net. For fruit farming, nets with higher level of light transmittance in regard to durability of materials and price are recommended. It's not yet entirely clear which part of the radiation they reflect (Nobel 1991, cit. in Germšek 2010).

Different types of anti-hail nets obstruct the passing of the light differently and have different life expectancies. The thinner the net and the bigger the meshes, the higher are the swings in transmittance levels (Blanke 2007). Grey nets represent the biggest share of the standard production. They consist of crystal fibres with added black fibres for better durability. Black anti-hail nets, in comparison to white ones, have longer life expectancy, lasting from 15 to 20 years, and blend into the colour composition of the landscape more easily, but decrease the light transmittance by $20 \%$ (Zadravec 2002, Germšek and Unuk 2014). White nets transmit more light (86\%), but at the same price come with less than a half of the life expectancy of a black net (Dobaja 2005); white net's life expectancy is between 7 and 9 years. Its weakness is also in its noticeability in nature, compared to the black net, which led to a compromise in net colours - grey and green nets. Due to dirt accumulation over the years, the difference in light transmittance between the types of nets decreases with time (Dobaja 2005). Light transmittance in sunny weather is lower with white and black net compared to the uncovered part. With the black net it is decreased by $25 \%$ and with the white one by $12 \%$. With red-white nets the transmittance is decreased by $14 \%$, with red-black ones by $18 \%$ and with green-black ones by 23\% (Blanke and Salomaklin 2008). Under a grey net, shading reaches up to $12 \%$ (Zadravec 1998, as cited in Kuzma 2011). Iglesias and Alegre (2006) proved that the differences in light transmittance due to the colour of the net were smaller in cloudy weather.

Blanke (2007) states that in the ecological conditions of Southern Europe, for single-colour and two-colour varieties of apples, which achieve apropriate colouring, or for varieties which are prone to sunburn, black nets are the most appropriate. White or crystal and grey nets are more appropriate for the apple orchardsin NW Europe, where the lack of sunlight is noted and where there is no risk of sunburn. Red nets seem inappropriate because of the higher level of shading and also because they cannot blend with the landscape.

Anti-hail nets are mostly made out of highly compressed polyethylene fibres, 228-356 $\mu \mathrm{m}$ wide. One of special characteristics of black and black-green nets is that they have two black longitudinal threads, while transparent and red nets have two transparent or two red longitudinal threads. Transverse single threads in black, red and green nets are black. Nets also differ in thread density. The anti-hail net with double knitting lets through only the smallest possible grain of hail. It has a double longitudinal and a single transverse knitting (Blanke 2007).

\section{Light exposure under the anti-hail net and substituting the lack of light with a reflective ground foil}

The fruit skin (fruit exterior) colour represents one of the basic parameters which attract the consumers; in the eyes of a buyer, it represents direct connection to the internal quality of the fruits (Sadar et al 2013). This is the main reason why growers use numerous measures to improve the colouring of fruits. Because of the decrease in light transmittance in orchards under the anti-hail net, the skin colour is even a bigger challenge for the growers.

Blanke (2004) states that a white reflective foil laid out between the rows of trees, improves the colouring of fruits of the 'Jonagold Wilmuta' variety. This impact is even bigger when the foil is laid out early, meaning in July instead of August. The improved colouring of the fruits with the use of reflective foil is confirmed in combination with the white and black net. It was established that the improved colouring of the fruits is achieved under white and black nets, if the reflect foil is laid on the ground at least six weeks prior to the harvest. While studying the impact of the reflective foil, Jakopič et al. (2007) confirmed that the foil under the net could compensate the decrease of light transmittance even in the last month before harvest, and that covering the ground of the orchard with the reflective foil had a positive effect on the fruits' (variety 'Fuji') exposure to light.

In the ecological conditions of the Fruit Growing Centre in Maribor (NE Slovenia), the impact of the anti-hail net and the ground reflective foil on the size and quality of yield (variety 'Jonagold' and 'Elstar') was not documented. However, the positive impact of the reflective foil on the fruit colouring was confirmed. The impact was the highest in combination with the crystal net ( $91.7 \%$ on the variety 'Elstar'). The highest impact on fruit colour ofthe variety 'Elstar' was recorded with the use of reflective foil (91.6\%), followed by the crystal net (91.7\%), the black net (84.9\%), control - without nets and reflective foil $(84.1 \%)$, reflective foil in combination with the black net $(80.8 \%)$ and reflective foil in combination with the crystal net (79.7\%). In 2002, the highest impact on fruit 
colour of the variety 'Elstar' was recorded with the use of crystal net (64.4\%), followed by reflective foil in combination with the crystal net (58.3\%), control (54.5\%), reflective foil in combination with the black net (51\%) and reflective foil (47.7\%). Regarding the variety 'Jonagold', the highest impact on fruit colour in 2001 was recorded when using the reflective foil in combination with the crystal net $(61.5 \%)$, followed by the crystal net (58.8\%), the black net (58.5\%) and reflective foil in combination with the black net (47.8\%). In 2002, the highest impact on fruit colour of the variety 'Jonagold' was recorded when using the reflective foil in combination with the black net $(78.1 \%)$, followed by reflective foil $(59 \%)$, the crystal net (58.6\%), the black net $(41 \%)$, reflective foil in combination with the crystal net (34.1\%) and control (21.7\%) (Dobaja 2005).

\section{The impact of anti-hail net on some quantity and quality parameters of fruits}

The optimal light conditions in the tree crown improve the health status and colour of the fruits (anthocyanin synthesis) (Awad et al. 2001). Light is very important for the increase in the anthocyanin level (Macheix et al. 1990). The less light reaches the treetops, the smaller is the intensity of photosynthesis, which in the end results in the lesser fruit colouring (Ubi et al. 2006). Different authors (Vercammen 1999, Widmer 2001,Zadravec 2002, Germšek and Unuk 2014) prove that the quantity of yield under the protective net does not decrease; many of them even state the opposite. Zadravec et al. (2009) and Germšek (2008) proved that the net does not impair the bearing fruit - on the contrary, they noted a better differentiation of flower buds on the trees under the net (which might also be due to the uncovered trees being damaged by hail). Anti-hail net does not affect the trunk width, growth of the annual shoots, the number of nodes, or any other aspect of the exuberance of growth (Germšek 2008).

Widmer (2001), Blanke (2007) and Zadravec et al. (2009) established that the external quality of the fruit (diameter) under the net does not worsen. Germšek and Unuk (2014) state that the average weight of fruits is bigger under the black net, while Zadravec (2002), Štampar et al. (2002) and Iglesias and Alegre (2006) did not notice any affect on the average weight of the fruits.

Internal quality is also becoming more and more important for the consumer. Many authors have established that the internal quality of fruits somewhat changes when grown under an anti-hail net; fruit firmness and acid content increase in certain years, but the content of dry matter typically decreases (Widmer 2001, Steinbauer 2008, cit. in Zadravec et al. 2009). Zadravec (2002) establishes that there is more soluble dry matter in fruit grown outside the net (fruit with better colour contains more dry matter). Likewise, Germšek and Unuk (2014) establish that apple fruit (variety 'Gala Brookfiel' and 'Fuji Kiku 8') grown under the black anti-hail net has a lower content of dry matter (from 0.6 to $1^{\circ} \mathrm{Brix}$ ). Štampar et al. (2002), Iglesias and Alegre (2006), Germšek and Unuk (2014) claim that hardness of the fruit is not linked to the anti-hail nets. Štampar et al. (2002) also establish at that cultivation under anti-hail nets does not influence the content of malic and fumaric acid, although the fruit grown under a black net contains more citric acid.

Zadravec (2002) and Germšek and Unuk (2014) noted that the starch decomposition in the fruit is slower under a net, which is a sign of slower ripening. More dry matter was measured in the fruit grown without a net (fruit with better colour contains more dry matter) and a lower starch index was established in the fruit grown under a net (Štampar et al. 2002, Zadravec 2002, Germšek and Unuk 2014). An antihail net causes minimal differences of individual sugars $(2 \mathrm{x}$ more glucose and fructose than sucrose) (Zadravec 2002). Štampar et al. (2002) prove the differences in glucose content (higher under black) and sucrose (higher under white), with no differences in fructose and sorbitol.

Fruit grown under the net is less exposed to sunburn, despite unchanged maximal leaf temperatures on trees (Zadravec 1998, cit. in Kuzma 2011). A lower risk of sunburn under anti-hail nets, especially under black nets, and consequently higher quality of the fruit's skin is also established by Štampar et al. (2002), Dussi et al. (2005), Iglesias and Alegre (2006). Zadravec (2002) establishes that $12 \%$ of fruit was sunburnt on trees without a net, $6 \%$ on trees under a white net and $5.5 \%$ on trees under a black net. Therefore, a reduction of light exposure is very welcome in extreme circumstances. Concerning the presence of sunburn, Steiermark recommends the use of black nets, woven with two fibres. Their experience shows that there was no sunburn on trees planted under a black net, whereas $6.5 \%$ of fruit was sunburnt on trees grown without a net; when a reflective foil was used for better fruit colour $9 \%$ of the fruit was sunburnt, on organic trees, where lime sulphur was used to protect from diseases, $16 \%$ of fruit was sunburnt (Caf 2009, cit. in Germšek 2010).

Casierra-Posada and Lüdders (2001), when studying the effect of summer pruning and mineral content of apple trees under anti-hail nets, have determined that anti-hail nets effect the content of minerals in sprouts and leaves. When pruned in June, the content of calcium and magnesium was higher in leaves. The fruit grown outside of a net had a higher content of calcium and potassium in comparison to the fruit grown under an anti-hail net. The fruit grown outside of a net has a higher calcium - potassium ratio in comparison to the fruit grown under a net. Growing fruit under a net decreases the ration between $(\mathrm{K}+\mathrm{Mg}) / \mathrm{Ca}$.

\section{Fruit skin colour under an anti-hail net}

The basic colour of apples comes from chlorophyll pigments, most of which is chlorophyll a and $b$ in a ratio 3 : 1. During ripening, the green colour turns to yellow, because of the forming of carotenoids (Hribar 1989). The ripening of red fruits leads to red colour in the fruit's skin. The decrease of green colour is connected to the decomposition of chlorophyll, while the red colour stems from the accumulation of anthocyanin (Macheix et al. 1990).The visual perception of colour is not only effected by the absolute concentrations of individual pigments in the fruit's skin but also by the proportions of the vacuoles and the distribution and size of 
the cells in the apple's skin. The final percept of the colour is a consequence of a combination of all previously listed factors (Curry 1997).

It has been proven that a net can influence the chlorophyll synthesis in leaves (depending on variety, growth period and planting distance), as the average levels of photosynthesis pigments in leaves under a net are lower than outside of it. According to Horvat (2011), anti-hail nets also have an influence on the smaller decomposition of chlorophyll and formation of red pigments in fruits' epidermis, which has been confirmed by Germšek and Unuk (2014). Because of the small variability in the fruit grown under the net, compared to that grown without a net, Germšek and Unuk (2014) claim, that at the time of the technological ripeness the an anti-hail net (black) does not have a negative impact on fruit skin colour in cases where the study was conducted on the better coloured clones (like the variety 'Gala Brookfield').

Also according to Preiffer and Jankovič (2004), the net has a positive effect on the fruit's colour, because the colouration of the fruits is more simmilar. The fruit skin colour is mostly genetically determined and depends on weather conditions, special Low night temperatures during ripening have a positive effect on the accumulation of anthocyanins in apples. Ubi et al. (2006) claim that low temperatures cause a lower consumption of carbohydrates for breathing and increase photosynthesis, which ultimately affects the biosynthesis of anthocyanin. Night time temperatures between 3 and 11 ${ }^{\circ} \mathrm{C}$ are supposedly most suitable for coloration (Iglesias and Alegre 2006). Optimal daytime temperatures for anthocyanin accumulation are between 15 and $25^{\circ} \mathrm{C}$, whilst optimal night time temperatures are between 10 and $20^{\circ} \mathrm{C}$. Vidrih and Hribar (2002) claim that the fruit's colour is more intense when the differences between day and night time are bigger, and that coloration is optimal if cold nights $\left(10-15^{\circ} \mathrm{C}\right)$ are followed by warm $\left(20-25^{\circ} \mathrm{C}\right)$ and sunny days.

Horvat (2011) believes that the research of anthocyanin content shows that anti-hail nets effect and slow down the decomposition of chlorophyll and formation of red pigments in the fruit's epidermis. Germšek and Unuk (2014) point to an average 7 day (variety 'Gala') and an average 10 day (variety 'Fuji') delay in the decomposition of chlorophyll in the fruit's epidermis.

This effect was reduced at the time of optimal technological ripeness or was not perceived in favourable weather conditions at the time of ripening.

Concerning fruit colour, Jakopič et al.(2007) states that the variety 'Fuji' shows no differences in colour under a net or outside of it. Zadravec (2002) claims that the use of anti-hail nets causes an inferior fruit colour, which is most obvious when the black net is used. In another experiment, Zadravec et al. (2009) establishes no negative impact of anti-hail nets on fruit colour, just a slight reduction of the quantity of fruits with the most desired colour.The red skin colour is slightly worse in two-coloured varieties, while fully red varieties show no negative impact on the colour of the epidermis (Blanke 2007). Germšek and Unuk (2014) have made an effort to show that the position of the fruit (variety 'Gala Brookfield' and 'Fuji Kiku') has a stronger effect on the dynamics of colour development than the anti-hail net itself.

\section{The impact of anti-hail nets on the microclimate of the orchard}

In an experiment that lasted several years in the Fruit Growing Centre Maribor - Gačnik, the measurements of daily temperatures have shown that nets somehow reduce momentary temperature fluctuations caused by sun exposure changes. Similar results were found when measuring relative air humidity. A smoother curve in daily temperatures and relative air humidity can mean somehow better or less stressful conditions for a tree, which could explain why the reduction of light does not result in lower production capabilities of the orchard under an anti-hail net (Zadravec 2002).

The use of the net in an experiment in Spain has shown differences in temperature under the net and outside of it. The maximum temperatures under the net were $3{ }^{\circ} \mathrm{C}$ lower, but only on sunny days. On cloudy days, the differences were negligible. The decrease of maximum temperatures are also confirmed by Torggler (2002) (cit. in Zadravec et al. 2009) by, from 0.3 to $0.4{ }^{\circ} \mathrm{C}$, Kührt et al. (2006) by $0,8^{\circ} \mathrm{C}$, and Solomakhin and Blanke (2008) by $0,2^{\circ} \mathrm{C}$, but only on sunny days. Zadravec (1998, cit. in Kuzma 2011) states that the somewhat smaller differences between maximum and minimum air temperatures could partly be the reason for delayed and lower fruit colouration.

Iglesias and Alegre (2006) also found a slight increase in relative air humidity under a net.They found a $2-6 \%$ increase of relative air humidity and, at the same time, a $11 \%$ decrease in evapotranspiration, which wasassociatedwith lower wind velocity. In comparison to measurements outside the net, an increase in relative air humidity from 0 to $8.9 \%$ was also determined under an anti-hail net by Torggler (2002, cit. in Zadravec et al. 2009).

A positive effect of anti-hail nets on fruit temperature has also been shown. Reduced fruit and leaf temperatures consequently mean less sunburn damage. A black net reduced the temperature of fruit by $4{ }^{\circ} \mathrm{C}$, a white net by $2.5^{\circ} \mathrm{C}$. On cloudy days with less light, the differences were smaller. The differences between air and fruit temperatures were also smaller than on sunny days (Iglesias and Alegre 2006).

The anti-hail net also affects the quantity of rain that gets to the ground. The differences in the measurements of rain fall(less under an anti-hail net) are probably the consequence of the measuring instrument accuracy, and only with very small quantities of rain would it be possible that a part of the rain is "intercepted" by the net and evaporates from it - so the rainwould not actually fall on the plants and ground in the orchard under the net (Zadravec et al. 2009).

The duration of the leaf dampness after rain, which is (c. 1 hour) longer under an anti-hail net, could only change the course of the incubation period for the apple scab in very specific infection circumstances. It is believed that black anti-hail nets do not prolong leaf dampness significantly and therefore do not increase the danger of certain diseases (Zadravec et al. 2009). 


\section{The impact of anti-hail nets on disease and pest development and mobility}

Reigne (1997) (cit. in Iglesias and Alegre 2006) argues that anti-hail nets do not have an effect on the occurrence of the codling moth. Demaria et al. (2006, cit. in Iglesias and Alegre 2006) and Zadravec et al. (2009) observed that there was a lower number of this pest under an anti-hail net and the damage to fruit was lower when compared to the part which was outside the net. Ferjanc (2009) believes that the net hinders the movement of codling moths, but claims that despite this there is no distinctive impact on the degree of fruit damage. Graf et al. (1999) have established that the net is an obstacle when the codling moths move in, but mostly does not hinder these moths moving out. In investigations associated with the effects of nets on mating of codling moths, there were no differences between the part of the orchard under the net and the part outside it, when the lure was placed on the height of $1.5 \mathrm{~m}$, while the difference was visible when the lure was placed on the height of $3 \mathrm{~m}$, as there were more fertilised females outside of the net (Tasin et al. 2008). Kührt et al. (2006) claim that individual stages of the codling moth development occur a few days later under the net because of lower temperatures. In accordance with thermoregulation in the phenology model, the stages appear four days later under the net, except for the first generation, where the occurrence is three days late. The development of the whole generation was one day shorter than outside the net. The delay of the occurrence of individual stages under the net, where thermoregulation was not integrated, was four days for all stages.

Reigne (1997, cit. in Iglesias and Alegre 2006) establishes that anti-hail nets do not influence the occurrence of plant lice, while Racskó et al. (2005) states the importance of temperature in the development of this pest. Because of lower wind speeds under the net, the migration conditions of plant lice are better, while the possibility of other pests is decreased. They also believe that delayed ripeness does not influence the development of larvae in the fruit. Ferjanc (2009) states that anti-hail nets with regular mesh size cannot physically prevent the plant lice from entering the orchard. He believes that the impact on the size of the plant lice population varies according to the type and manner of migration between hosts.

Graf et al. (1999) and Tasin et al. (2008) have established that more fruit was damaged from caterpillars in orchards outside of nets. Zadravec et al. (2009) claim that the plant lice population develops faster and better under an anti-hail net. Ferjanc (2009) believes that the red plant lice develops better outside the anti-hail net, but states that the impact on the occurrence of this pest differs depending on fruit varieties ('Braeburn', 'Gala' and 'Fuji').

Reigne (1997) (cit. in Iglesias and Alegre 2006), Zadravec et al. (2009), Ferjanc (2009) notethat anti-hail nets do not have an effect on diseases, such as, for example, apple scab and powdery mildew. Ruegg (1997) (cit. in Widmer 2001) also emphasizes that the leaves under the net, compared to those outside the net, do not stay damp long enough, which is why the possibility of apple scab infections is lower. Zadravec et al. (2009) state that the duration of the leaf dampness after rain, which is (app. 1 hour) longer under an anti-hail net, could only change the course of the incubation period for apple scab in very specific infection circumstances.

\section{CONCLUSION}

Numerous researchers have demonstrated different experiences with anti-hail nets. It maybe reasonable to set experiments for each specific situation, where a wider selection of different types of anti-hail nets (with different colours and structures) would be integrated. In order to obtain reliable data, more experiments would have to be carried out in individual topics of great interest (the impact of anti-hail nets on the development and movement of pests, development of diseases, fruit quality, vegetative reactions of cultivated plants to conditions under anti-hail nets...), since the current research shows that some subjects and factors are poorly explored and that information on the effects of anti-hail nets is incomplete. In the future, it would beuse ful that experiments associated with anti-hail nets and their impact would include less explored topics (irrigation needs, tendencies of natural undeveloped fruit pruning under anti-hail nets...). More coherent findings and a more comprehensive understanding of these impacts in different researches would lead to more uniform conclusions which are urgently needed in practice.

\section{REFERENCES}

1. Awad MA, Wagenmakers PS, Jager A. Effects of light on flavonoid and chlorogenic acid levels in the skin of 'Jonaglod' apples. Sci. Hortic. 2001;88:289-298.

2. Blanke M. Can reflective ground cover compensate for light losses under hail nets? Acta Hortic. 2004;732:669673.

3. Blanke M. Farbige Hagelnetze: Ihre Netzstruktur sowie Licht- und UV - Durchlässigkeit bestimmen die Ausfärbung der Früchte. Erwerbs-Obstbau. 2007;49(4):127-139.

4. Blanke M, Solomakhin A. Coloured hail nets alter light transmission, light spectra, phytochrome as well as vegetative growth, leaf chlorophyll and photosynthesis and reduce flower induction in apple. Plant Growth Reg. J. 2008;11:211-218.

5. Casierra - Posada F, Lüdders P. Influence of summer pruning and nitrogen nutrition on mineral content in apple trees under hail protection net. Erwerbobstbau 2001;43:106-113.

6. Curry EA. Temperatures for optimum anthocyanin accumulation in apple tissue. J. Hortic. Sci. 1997;72:723729.

7. Dobaja K. Vpliv talne reflektivne folije, protitočne kristalne in črne mreže na notranjokakovost plodov pri jablani (Malus domestica Borkh.) sorte 'Jonagold' in 'Elstar' [diplomsko delo]. Maribor: Fakulteta za kmetijstvo in biosistemske vede, Univerza v Mariboru, 2005.

8. Dussi MC, Giardina G, Reeb P. Shade nets effect on 
canopy light distribution and quality of fruit and spur leaf apple cv. 'Fuji'. Span. J. Agric. Res. 2005;3(2):253260.

9. Ferjanc B. Vpliv protitočne mreže na razvoj škodljivcev in bolezni jablane (Malusdomestica B.) [diplomsko delo]. Maribor: Fakulteta za kmetijstvo in biosistemske vede, Univerza v Mariboru, 2009,

10. Germšek B. Vpliv protitočne mreže na rast, rodnost in kakovost pridelka jabolk (Malus domestica B.) sorte 'Gala'[diplomsko delo]. Maribor: Fakulteta za kmetijstvo in biosistemske vede, Univerza v Mariboru, 2008,

11. Germšek B. Razvoj parametrov kakovosti jabolk sort 'Gala' in 'Fuji' kot posledica vpliva protitočne mreže in položaja plodov v krošnji [magistrsko delo]. Maribor: Fakulteta za kmetijstvo in biosistemske vede, Univerza v Mariboru, 2010,

12. Germšek B, Unuk T. Kakovost jabolk sort 'Gala Brookfiel' in 'Fuji Kiku' pod in izven protitočne mreže. Acta agricult. Slov. 2014;103(1):137-144.

13. Graf B, Höpli H, Rauscher S, Höhn H. Hagelnetze beeinflussen das Migrationsverhalten von Apfel - und Schalenwickler. Obst - Weinbau 1999;12:289-292.

14. Holzwarth R. Hagelschutznetze: Moderne Technik schützt das Obst. Besseres Obst 2008;6:25.

15. Horvat $\mathrm{S}$. Vpliv protitočne mreže na obarvanost plodov jablane (Malus domestica Borkh.) [diplomsko delo]. Ljubljana: Biotehnična fakulteta, Oddelek za agronomijo, Univerza v Ljubljani, 2011,

16. Hribar J. Spremembe kemičnih in mehaničnih lastnosti jabolk sorte 'Jonagold' pri različnih pogojih skladiščenja [doktorska disertacija]. Ljubljana, BF, VTOZD za živilsko tehnologijo, 1989,

17. Iglesias I, Alegre S. The effect o anti - hail nets on fruit protection, radiation, temperature, quality and profitability of 'Mondial Gala' apples. J. App. Horticult. 2006; 8(2):91-100.

18. Jakopič J, Veberič R, Štampar F. The effect of reflective foil and hail nets on the lighting, color and anthocyanins of 'Fuji' apple. Sci. Horticult. 2007;115(1):40-46

19. Jazbec M, Honzak J. V sadnem vrtu, moj vrt moje veselje. Ljubljana, Kmečki glas, 1982:38.

20. Klein K. Vpliv protitočne mreže na kakovost plodov jablan [diplomsko delo]. Maribor: Fakulteta za kmetijstvo in biosistemske vede, Univerza v Mariboru, 2000,

21. Kuzma S. Vpliv protitočnih mrež na kakovost plodov žlahtne jablane (Malus domestica Borkh.) [diplomsko delo]. Ljubljana: Biotehnična fakulteta, Oddelek za agronomijo, Univerza v Ljubljani, 2011,

22. Kührt U, Samietz J, Höhn H, Dorn S. Modelling the phenology of codling moth: Influence of habitat and thermoregulation. Agric. Ecosyst Environ. 2006;117:2938.

23. Larcher W. Physiological plant ecology: Ecophysiology and stress physiology of functional groups , 4th edn., Berlin: Springer, 2003,

24. Macheix J.-J, Fleuriet A, Billot J. Fruit phenolics. Boca Raton, CSR Press, 1990,

25. Preiffer M, Jankovič P. Obvladovanje tveganja pri pridelavi sadja s pomočjo protitočnih mrež sistema
Wiesel. V: Zbornik referatov 1. Slovenskega sadjarskega kongresa z mednarodno udeležbo. Krško, 24.- 26. marec. Ljubljana, 2004:249-253.

26. Sadar N, Urbanek Krajnc A, Unuk T. 2013. Spectrophotometrically determined pigment contents of intact apple fruits and their relations with quality: a review. Zemdirbyste-Agriculture vol. 2013;100:105111., No. 1 (2013)

27. Steinbauer L. Treffen der Arbeitsgruppe »Obstbau unter Hagelnetzen. Haidegger Perspektiven 2008;3:6-7.

28. Štampar F, Veberic R, Zadravec P, Hudina M, Usenik V, Solar A and Osterc G. Yield and fruit quality of apples cv. 'Jonagold' under hail protection nets. Gartenbauwissenschaft 2002;67(5):205-210.

29. Tasin M, Demaria D, Ryne C, Cesano A, Galliano A, Anfora G, Loriatti C, Alma A. Effect of anti-hail nets on Cydia pomonella behaviour in apple orchards. Entomologia experimentalis et applicata 2008;129(1):3236.

30. Ubi BE, Honda C, Bessho H, Kondo S, Wada M, Kobayashi S, Moriguchi T. Expression analysis of anthocyanin biosynthetic genes in apple skin: Effect of UV - B and temperature. Plant Sci. 2006;170(3):571578.

31. Vercammen J. Eerste ervaringen met hagelneten - ten in Belgie. Fruitteelt - nieuws 1999;12:6-8.

32. Vidrih R, Hribar J. Optimalni rok obiranja sadja. Brstika. Priloga tednika kmečki glas za sadjarje in vinogradnike. 2002;1,3:4-5.

33. Zadravec P. Vpliv protitočne mreže na količino in kakovost pridelka pri jablani. Sodobno kmetijstvo. Kmečki glas 2002;35(3):108-111.

34. Zadravec P, Donik B, Beber M, Unuk T, Tojnko S, Lešnik M, Germšek B, Ferjanc B. Odziv jablane in škodljivih organizmov na spremenjene razmere pod protitočnimi mrežami. Monografija, Sadjarski posvet, 2009:38-44.

35. Widmer A. Beschattung unter weissen und grauen Hagelnetzen. Obst und Weinbau 2001a;133:581-583.

36. Widmer A. Light intensity and fruit quality under hail protection nets. Acta Hort. 2001b;557:421-426. 


\section{Vpliv različnih tipov protitočnih mrež na prepustnost svetlobe in parametre kakovosti jabolk - pregledni članek}

\section{IZVLEČEK}

Danes protitočne mreže predstavljajo osnovno opremo v nasadih jablan. Zmanjšujejo rizik pridelave in hkrati omogočajo redne pridelke jabolk visoke kakovosti. Različne barve mreže različno močno ovirajo prehod svetlobe, kar ima neposredni vliv na parametre kakovosti pridelka, posebej obarvanost. Članek vkjučuje kratki pregled objav, povezanih s prepustnostjo svetlobe svozi različne tipe protitočnih mrež ter posledično vpliv na kakovost plodov. Vključene so tudi vsebine raziskav, ki tečejo na temo prilagoditve posameznih tehnoloških ukrepov v nasadu, kot je to npr. uporaba reflektivne folije. Nekaj zbranih informacij, ki jih lahko najdemo $\mathrm{v}$ literaturi, pa pojasnjuje vpliv protitočnih mrež na vzpostavitev mikroklime $\mathrm{v}$ nasadu ter posledično vpliv na razvoj in dinamiko pojava posameznih bolezni in škodljivcev. 